\title{
Za profesorem Miroslavem Zahrádkou
}

\author{
Ivo Pospíšil \\ (Brno, Česká republika)
}

Dne 25. května 2021 zemřel po dlouhé nemoci ve věku devadesáti let prof. PhDr. Miroslav Zahrádka, DrSc., český rusista mezinárodní pověsti, s jehož jménem jsou spjaty desítky let československé rusistiky a prijímání ruské literatury u nás.

Psal jsem o M.Zahrádkovi mnohokrát (i když moje jméno bylo z mnoha bibliografických pojednání o Zahrádkovi novodobými cenzory důsledně vymazáno) a dvakrát $\mathrm{k}$ jeho kulatým jubileím: $\mathrm{k}$ sedmdesátinám a osmdesátinám. ${ }^{1}$ Proto tento nekrolog pojmu více osobně, i když se jeho dílo pokusím také komplexně a snad i objektivně zhodnotit s využitím svých zmíněných souborných statí. Ty jubilejní články vycházely v době, kdy byl prof. Miroslav Zahrádka terčem necitlivé kritiky a byli to také někteří brněnští rusisté, kteří vystoupili na jeho obranu. Sám jsem musel zcela v obklíčení radikálních, jinak smýšlejících kritiků z Prahy, Olomouce i Brna čelit kritice nejen zvěčnělého badatele, ale předlistopadové rusistiky jako takové ${ }^{2}$ a přiznám se, že jsem to dělal rád.

Jako mladý asistent jsem vnímal Zahrádkovu osobnost jako spíše konzervativního literárního vědce, který př́liš nepřeje novým postupům, jež jsem se snažil uplatňovat, nebo je k nim skeptický. Avšak jeho lidské postoje v období, kdy byl v podstatě klíčovou rusistickou osobností, jsem vždy oceňoval a měl jsem s tím i osobní zkušenost, mimo jiné s dramatickou obhajobou své kandidátské disertace. Zahrádka byl nejen prominentní rusista a ten, kdo po léta tvaroval českou recepci ruské literatury u nás, ale především čestný člověk, což je dodnes právě v akademickém prostředí vzácnost. Psal jsem o něm již předtím v populárním tisku, např. o jeho knížce, která se týkala poetiky díla M. Šolochova, a poté jsem komentoval takřka vše podstatné, co napsal až do poslední doby, kdy mu vážná nemoc znemožnila další práci. ${ }^{3}$ To, co jsem na

\footnotetext{
1 [POSPÍŠIL 2001b; POSPÍŠIL 2011].

2 [POSPÍŠIL, TRÁVNÍČEK 2004]. Text I. Pospíšila na s. 26, 27, 28, 29, 30, 31, 32.

3 Viz naše recenze: [POSPÍŠIL 1976; POSPÍŠIL 1981; POSPÍŠIL 1982; POSPÍŠIL 1992; POSPÍŠIL 2001a; POSPÍŠIL 2002; POSPÍŠIL 2006].
} 
něm obdivoval a obdivuji nejvíc: systematičnost, důslednost, pracovitost, team spirit, schopnost vést a ovlivňovat, stát na svém, byt’ někdy s kompromisy.

M. Zahrádka žil a tvořil v ne právě příznivé době, ačkoli se to na první pohled nezdálo a nezdá: nejprve nutnost ztotožnit se s vládnoucí ideologií, což bylo u něho spjato s rodinnou anamnézou, později deziluze a nárazy let 1968-1969 a 1989, to vše lidí nejen jeho generace nemohlo nepoznamenat. I když se musel často podrobovat, nemyslel jen na sebe, ale hlavně na svůj obor a své akademické pracoviště a kolegy, které držel často politicky nad vodou. Byl iniciátorem Olomouckých dnů rusistů a zakladatelem sborníku, který posléze přerostl v časopis, organizátorem a účastníkem, mezinárodních konferencí, často jezdil do zahraničí, podílel se na vydávání ruských sovětských autorů u nás, popularizoval je, psal ke knihám interpretační doslovy a hodnoticí stati. Jeho aspirantské semináře utvářely i dnešní osobnosti české rusistiky.

Narodil se 14. května 1931 v Kralupech nad Vltavou v dělnické rodině. Vystudoval češtinu a ruštinu na Karlově univerzitě (1950-1955), velmi rychle se stal asistentem na tehdejší Vysoké škole ruského jazyka. Po absolvování vědecké aspirantury v Moskvě na Lomonosovově univerzitě (1956-1960, disertace: Umělecký styl románů Konstantina Fedina, vyšlo později u nás) spojil celý svůj osobní i profesní život s Olomoucí. Byl dobrým hospodářem na svém pracovišti, dokázal se zastat svých lidí, byl k nim loajální a oni $\mathrm{k}$ němu: to se ani dnes $\mathrm{v}$ takovém rozsahu nikde nevidí a nevidělo, zvláště když šlo o situace po roce 1970 a 1989.

Svůj článek k jubilantovým sedmdesátinám jsem kdysi nadepsal Hledání rudimentárního ruství a další Významná osobnost československé rusistiky a nemusel bych na tom nic zásadního měnit; proto z nich v této části textově vycházím. Každá generace si myslí, že přináší něco, co zásadně mění vše, tedy i vědní obor. U Zahrádky je cenná jeho návaznost na minulé hodnoty i to, že šel vždy svou cestou, současně však budoval obor a má žáky, kteří se k němu hlásí: to o sobě nemůže z různých důvodů říci každý, nebơ i naše filologické vědy skýtají mnohé př́pady velkých badatelů, v jejichž práci, často nikoli jejich vinou, nikdo nepokračuje. Zahrádkovi rusisté, nyní již většinou staršího středního a staršího věku, jsou rozeseti po celém bývalém Československu. Jestliže bych české rusisty schematicky rozdělil na ty, kteří k Rusku přikládají spiše evropská měřítka a evropské hodnoty, a na ty, kteří naopak vycházejí z ruského specifika a pak teprve hledají možnosti srovnávání a širší souvislosti, musel bych Miroslava Zahrádku přiřadit $k$ té druhé: jeho vědecká tvorba od samého počátku směřovala $k$ analytickému ponoru do materiálu. Byly mu vzdálené teoretické konstrukce nepodložené tvrdou prací, studiem a zvažováním detailu a v ruské literatuře především toho, co ji odlišuje, čím je specifická; to našel, jak známo, mimo jiné v látkovém i formotvorném tématu války.

Zahrádkovu literárněvědnou aktivitu lze rozdělit na několik oblastí: zkoumání válečné literatury, zejména prózy, rusko-české literární vztahy, literárněhistorická 
analýza ruské literatury 20. století (osobnosti, směry, styly) a systematické sledování ruské literární, zejména prozaické produkce. V tomto smyslu Miroslav Zahrádka byl a je jedním z mála rusistů, kteří byli současně literárními kritiky, popularizátory a vykladači.

Na počátku řady jeho literárněvědných monografií stojí studie $O$ vývoji ruské válečné prózy: téma - žánr - styl (1812-1853), která vyšla v Olomouci roku 1969. Válce jsou věnovány ještě další dvě práce, a to Stalingradská bitva v literárním zobrazení: téma žánr - styl (Ostrava 1973, 2. vyd. 1975) a Literatura a válka: etapy a tendence zobrazení Velké vlastenecké války v sovětské literatuře (Praha 1980). Česko-ruským literárním vztahům jsou věnovány dva knižní soubory: Alexandr Fadějev a Československo (spolu se Ctiradem Kučerou, Ostrava 1976) a Sovětská literatura a my (1981). Jubilant také vedl autorský kolektiv Malého slovníku rusko-českých literárních vztahů (osobnosti ruské literatury v českém kontextu), který vyšel v Lidovém nakladatelství v Praze roku 1986. Nejbližší je mi však jiná Zahrádkova knihu ze 7o. let: Michail Šolochov. Motivy kompozice - styl (Lidové nakladatelství, Praha 1975). Právě zde dokázal jubilant maximálně propojit tematologii s kategoriemi poetiky, se stylem, symbolikou a popisy přírody. Na sklonku 8o. let 20. století vychází kniha, kterou Zahrádka napsal spolu s jiným olomouckým rusistou a básníkem Dušanem Žváčkem pod názvem Současná sovětská literatura let osmdesátých (Olomouc 1989). K problémům tzv. socialistického realismu se jubilant kriticky vrací v brožuře Dogmata a živý literární proces s podtitulem Jak vznikala úzká norma socialistického realismu a jak s ní ruská literatura bojovala (Olomouc 1992). Další publikací vyrovnávající se se současnou literaturou byl Ruský literární proces 8o. a začátku 9o. let (Olomouc 1994). Kromě toho je Zahrádka autorem kompendia Současní ruští prozaici (Plzeň 1997).

Jádrem Zahrádkovy literárněvědné produkce 9o. let je však nepochybně dlouho očekávaná monografie L. N. Tolstoj. Po dlouholetých odbočkách, jimiž Zahrádka obohatil českou recepci ruské literatury, se tu vrací k hutné, analytické, faktografií nasycené práci, v níž zkoumá souvislosti Tolstého prózy s jinými ruskými autory, jako byli mj. M. J. Saltykov-Ščedrin, I. S. Turgeněv, V. M. Garšin nebo A. Kuprin. Jak jsme již napsali jinde, Zahrádkovo celoživotní zaujetí tzv. válečnou prózou vyvolávalo dvojí reakce: uznání i kritiku, nebot̉ bylo někdy chápáno jako málo literární a umělecké. Zahrádka však prokázal, že zkoumání této specifické vrstvy v ruské literatuře má svůj smysl a přispívá k poznání onoho rudimentárního ruství, bez něhož bychom ruské literatuře tak dobře neporozuměli. Per aspera ad astra: literárněvědná práce je pro něho tvrdým bojem s kluzkostí materiálu a úporným hledáním tematických a myšlenkových souvislostí; v této konkrétnosti a hutnosti, stejně jako ve schopnosti kritického hodnocení pramenů a umění formulační zkratky je síla Zahrádky jako literárního vědce, síla, která tvaruje jeho badatelský profil a vybudovala jeho nezastupitelné místo $\mathrm{v}$ československé rusistice. 
O jeho bohaté činnosti v 21. století svědčí reprezentativní Bibliografie (Olomouc 2010) a doplněný a rozšířený Slovník rusko-českých literárních vztahů (Oftis, Ústí nad Orlicí 2008), kolektivní dílo, které je také jeho dítětem, Maxim Gorkij v ohlasech české kritiky prelomu 19. a 20. století (2001), učebnice Ruská literatura XIX. století v kontextu evropských literatur (osobnosti a dialog literatur, 2005) a Ruská literatura XX. století (literární proudy a osobnosti, 2003), Toulky s ruskými spisovateli (Oftis, Ústí nad Orlicí 2007). Zahrádka je dominantním vykladačem podstatných směrů moderní ruské prózy svými studiemi a doslovy ke knihám řady autorů (A. Fadějev, A. Adamovič, D. Granin, M. Gorkij, D. Furmanov, V.Ličutin, I. Druţă, J. Bondarev, A. Prochanov, M. Šolochov, G. Baklanov, K. Simonov, A. Bek, V. Bělov).

Nelze opomenout ani Zahrádkovu práci prozaika (pod pseudonymem Petr Klen). Jde o román Čekání (Kronika mládí, 1980), který zachycuje časový úsek 1942-1950, je silně autobiografický a má jistě i přesah dobový, např́íklad pokud jde o téma převlékačů kabátů a všeobecné české připravenosti zrazovat přátele a přesvědčení. Hodně očekávány byly i Zahrádkovy paměti (čekalo se na to, co tam uvede a co naopak nikoli, nebot toho věděl opravdu mnoho a to je vždy nebezpečné): vyšly nakonec jako stylizované fragmenty pod názvem Okamžiky ze životního putování literárního vědce a prozaika (Vzpomínky, 2011). A není to čtení nudné, spíše naopak.

S charakterem M. Zahrádky souvisí i jeho „pokryvačská“ činnost za normalizace (Antonín Václavík, Josef Sedlák) a také uvádění prací druhdy začínajících vybraných rusistů, např́klad známé „mozaiky sovětské literární skutečnosti“ Odpovědnost tvorby Vladimíra Novotného, kdysi svého olomouckého aspiranta. Jistě si na zvěčnělého učitele jeho tehdejší žáci i nyní s vděčností vzpomenou.

Práce a osobnost prof. Miroslava Zahrádky se těšily všeobecné vážnosti v odborných českých, československých a evropských kruzích i mezi milovníky ruské literatury. Budiž nám všem toto vědomí útěchou v těchto těžkých chvílích.

\section{Bibliografie:}

POSPÍŠIL, I. (1981): Dějiny a teorie válečné literatury. Literární měsičník, 1981, č. 1, S. $110-111$.

POSPÍŠIL, I. (1992): Dogmata a literatura (M. Zahrádka: Dogmata a živý literární proces, Olomouc 1992). Lid. demokracie, 19. 11. 1992, s. 5.

POSPÍŠIL, I. (2001a): Gorkij nebyl (ani u nás) umělou bublinou (M. Zahrádka: Maxim Gorkij v ohlasech české kritiků přlomu 19. a 2o. století. Vydala česká koordinační rada Společnosti prátel národů Východu za přispění Ministerstva zahraničí ČR, Olomouc 2001). Opera Slavica XI, 2001, č. 3, s. 53-54. 
POSPÍŠIL, I. (2001b): Hledání rudimentárního ruství. In: SPFFBU X 4. Brno, s. 107-109. POSPÍŠIL, I., TRÁVNÍČEK, J. et al. (2004): Kostlivci ve skřini. Diskuse $i$ „kulatého stolu“ o stavu současné rusistiky. HOST, 2004, č. 8, s. 26-32.

POSPÍŠIL, I. (1976): Poetika Šolochovovy prózy (M. Zahrádka: M. Šolochov. Motivy kompozice - styl, Praha 1975). Rovnost, 8. 1. 1976, s. 5.

POSPÍŠIL, I. (2006): Ruská literatura a svět (Miroslav Zahrádka: Ruská literatura XIX. století v kontextu evropských literatur (Osobnosti a dialog literatur). Periplum, Olomouc 2005, 279 s.). Opera Slavica XVI, 2006, č. 1, s. 53-54.

POSPÍŠIL, I. (1982): Síla dokumentu (M. Zahrádka: Sovětská literatura a my, Praha 1981). Rovnost, 9. 2. 1982, s. 5 .

POSPÍŠIL, I. (2002): Užitečný přehled ruské literatury 2o. století, část druhá: tečky, vykřičníky a otazníky. (M. Zahrádka - F. Sováková: Literaturnyje tečenija i ličnosti russkoj literatury XX veka. II čast’. Západočeská univerzita, Plzeň 20oo, 110 s.). Opera Slavica XII, 2002, č. 3, s. 53-54.

POSPÍŠIL, I. (2011): Významná osobnost československé rusistiky (K osmdesátinám profesora Miroslava Zahrádky). Novaja rusistika 4, 2011, č. 1, s. 87-90.

\section{Summary}

\section{In Memory of professor Miroslav Zahrádka}

The present obituary deals with the personality of the Czech specialist in Russian literature Miroslav Zahrádka, author of tens of books and hundreds of studies mainly devoted to the four scholarly spheres: Russian war literature, sometimes even in comparative perspective, Czech-Russian literary relations, poetics of significant figures of both classical and modern Rusaian writers, and, last but not least, lexicographical works, including the two editions of the Minor Dictionary of Czech-Russian Literary Relations (The Personalities of Russian Literatures in the Czech Environment). Per aspera ad astra: His studies in Russian literature has always been a hard struggle with the slipperiness of literary material and persistent search for thematic and ideological contexts; his concreteness and conciseness as well as his ability of the critical assessment of sources and the art of condensed formulations represent Zahrádka's strength as a literary critic which forms his character and his irreplaceable position in Czechoslovak Russian studies.

\section{About the author}

Ivo Pospíšil, Masaryk University, Faculty of Arts, Department of Slavonic Studies, Brno, Czech Republic, ivo.pospisil@phil.muni.cz 
